\title{
The verification of adiabatic model of a lateral sliding bearing with a floating ring bearing
}

\author{
Aleksander Mazurkow \\ Rzeszow University of Technology, The Faculty of Mechanical Engineering and Aeronautics, \\ Dept. of Mechanical Engineering, Powstancow Warszawy Avenue 8, 35-959 Rzeszów, Poland \\ amazurkow@gmail.com
}

\begin{abstract}
This research work describes the adiabatic model of a lateral slide bearing with a floating ring bearing. In order to support recommended assumptions for a designed model and for an evaluation accuracy of achieved results, the author developed a verification method which let comparing results received in a numerical way with that of the ones received in experimental tests. The evaluation criteria of a theoretical model were presented in regard to results from empirical studies. These criteria were divided into three groups. As the basic criteria, the author accepted the position of a bearing journal centre towards a fixed bearing bush, also for these positions pressure and temperature distributions in the outer oil film were chosen. In the conclusion, suggestions were made about the comparison of pressure and temperature distributions, frictional moments on a fixed bush surface, and angular velocities of a floating ring bearing towards a fixed bearing bush. The reasons of differences between measured and calculated values were also discussed.
\end{abstract}

Keywords: Floating ring bearing, bearing load, oil film, adiabatic model, eccentricity ratio.

Register of symbol: B -bearing width [m], $B^{*}=B / D_{i}$ - bearing relative width, $\mathrm{c}_{\mathrm{p}}$ - specific heat measured at the constant pressure $\left[\mathrm{J} / \mathrm{kg} \cdot{ }^{0} \mathrm{C}\right] \quad \mathrm{C}_{\mathrm{Ri}} \quad-\quad$ radial clearance $[\mathrm{m}], \quad C_{R}^{*}=C_{R 2} / C_{R 1}$ - quotient of radial clearances, D- diameter [m], e- eccentricity [m], F- bearing load [N], $F^{*}=\frac{4 \cdot \psi_{1}^{2}}{B^{*} \cdot D_{1}^{2} \cdot \eta_{0} \cdot \omega_{1}} \cdot F$ - dimensionless bearing load, $\mathrm{F}_{\mathrm{L}}$ - oil film load capacity [N], h- lubricant gap height [m], $h_{i}^{*}=h_{i} / C_{R i}$ - dimensionless lubricant gap height, $\mathrm{M}$ - moment [Nm], $\mathrm{n}$-rotational speed [rps], $P e=\left(v_{i} \cdot R_{i} \cdot \rho \cdot c_{p}\right) / \lambda$ - Pecklet number, $\mathrm{p}$-pressure $\left[\mathrm{N} / \mathrm{m}^{2}\right], \mathrm{p}_{z}$ - oil feeding pressure $\left[\mathrm{N} / \mathrm{m}^{2}\right], p_{i}^{*}=p_{i} \cdot \frac{\psi_{i}^{2}}{\eta_{O} \cdot \omega_{i}}-$ dimensionless pressure of oil film, $Q_{b^{-}}$volumetric flow of rate $\left[\mathrm{m}^{3} / \mathrm{s}\right], \mathrm{Q}_{\mathrm{m}^{-}}$mass flow $[\mathrm{kg} / \mathrm{s}], \quad \mathrm{T}$-temperature $\left.{ }^{0} \mathrm{C}\right]$,$T_{i}^{*}=\frac{\rho \cdot c_{p} \cdot \psi_{i}^{2}}{\eta_{o} \cdot \omega_{i}}\left(T_{i}-T_{O}\right)$ - dimensionless oil film temperature, $\mathrm{T}_{\mathrm{z}}$ - oil feeding temperature $\left[{ }^{0} \mathrm{C}\right], \mathrm{T}_{0}$-reference temperature $\left[{ }^{0} \mathrm{C}\right]$, $\mathrm{T}_{\text {oli }}$ - oil temperature in feeding gap $\left[{ }^{0} \mathrm{C}\right]$, v-speed $[\mathrm{m} / \mathrm{s}], \mathrm{x}_{\mathrm{i}}=\varphi_{\mathrm{i}} \cdot \mathrm{R}_{\mathrm{i}}$ - Cartesian coordinate in circumferential direction, $\mathrm{y}$ - Cartesian coordinate in radial direction, $\mathbf{z}$ - Cartesian coordinate in axial direction, $\beta$ - an angle contained between lines going through centres of bearing journals and the beginning of angular coordinates $\varphi_{i}$. measured to the minimal height of a lubricant gap, $\varepsilon_{\mathrm{i}}=\mathrm{e}_{\mathrm{i}} / \mathrm{C}_{\mathrm{Ri}}{ }^{-}$ oil film relative eccentricity, $\varepsilon_{0}=e_{0} / C_{R 0}$ - resultant relative eccentricity, $\eta$ - oil dynamic viscosity [Pa.s], $\eta_{0^{-}}$oil viscosity in reference temperature $[\mathrm{Pa} \cdot \mathrm{s}], \lambda$ - thermal conductivity factor [W/ $\mathrm{m} \cdot \mathrm{deg}], \rho$ - oil density $\left[\mathrm{kg} / \mathrm{m}^{3}\right], \psi_{i}=C_{R i} / R_{i}$-relative clearance, $\omega_{i}$ - angular speed [1/s].

Subscripts. J- relates to journal for inner oil film it is journal rotor, whereas for outer oil film it is floating ring, $\mathrm{i}=1$ - relates to inner oil film, i=2- relates to outer oil film, ${ }^{*}$ - relates to dimensionless dimension.

Introduction

In a lateral sliding bearing with a floating ring bearing (Fig.1) in a thermohydrodynamic balance position, the constant load $F$ in its course and its value which is attached to the bearing journal is balanced by hydrodynamic load capacity of the inner bearing $F_{L 1 y}$ as well as the outer bearing $F_{L 2 y}$ (Fig. 2). The centre of a journal $\left(\mathrm{O}_{\mathrm{J} 1}\right)$ and a floating ring bearing $\left(\mathrm{O}_{\mathrm{J} 2}\right)$ is moved in an eccentric way and the centre of a fixed bearing bush $\left(\mathrm{O}_{2}\right)$. Values of journals centres displacements define
Research article

CIndian Society for Education and Environment (iSee)
A. Mazurkow Indian J.Sci.Technol. 
eccentricities $\left(e_{1}, e_{2}, e_{0}\right)$ whereas, the distance between the straight of a bearing load and the straight of an oil film load capacity define displacements $\left(\mathrm{e}_{1}, \mathrm{e}_{2}\right)$.

Frictional moments $M_{2}\left(O_{\mathrm{J} 2}\right),\left(M_{3}\left(O_{\mathrm{J} 2}\right)\right.$, which appear on the surface of the outer and inner floating ring bearing are equal. Frictional moments on the journal and a fixed bush surfaces stand for: $M_{1}\left(O_{\mathrm{J} 1}\right)$ and $\mathrm{M}_{4}\left(\mathrm{O}_{\mathrm{J} 2}\right)$. Further information concerning the lubricant film geometry is presented in a research work (Mazurkow, 2009).

To design a theoretical model the author took into account assumptions concerning oil flow and heat in a bearing, bearing elements structure as well as a lubricant oil. These presumptions were described in research works (Kaniewski, 1977; Mazurkow, 1993). Models were solved by a finite difference method which is clearly described in a work (Mazurkow, 1993). In order to support recommended assumptions for a designed model and for an evaluation accuracy of achieved results we developed a verification method which let us compare results received in a numerical way with ones received in experimental tests. The author of the discussed above method benefited from experiments conducted by (Buluschek, 1980).

\section{Equations of a bearing mathematical model}

Model of bearing is described by equations in a dimensionless way:

Equations of pressures distribution in lubricant gaps ( $i=1$, 2):

$\left(\frac{\partial^{2} \mathrm{p}_{\mathrm{i}}^{*}}{\partial \varphi_{\mathrm{i}}^{2}}\right)+\left(\frac{D_{i}}{B}\right)^{2}\left(\frac{\partial^{2} \mathrm{p}_{\mathrm{i}}^{*}}{\partial \mathrm{z}^{* 2}}\right)+\frac{3}{\mathrm{~h}_{\mathrm{i}}^{*}} \frac{\partial \mathrm{p}_{\mathrm{i}}^{*}}{\partial \varphi_{\mathrm{i}}} \frac{\partial \mathrm{h}_{\mathrm{i}}^{*}}{\partial \varphi_{\mathrm{i}}}=\frac{6 \cdot \eta^{*}}{\mathrm{~h}_{\mathrm{i}}^{* 3}} \frac{\omega_{i} R_{i}+\omega_{i+1} R_{i+1} \partial \mathrm{h}_{\mathrm{i}}^{*}}{\omega_{\mathrm{i}} R_{i}}(1)$ Equations of lubricant gaps height $(i=1,2)$ :

$\mathrm{h}_{i}^{*}=\frac{h_{i}}{C_{R i}}=1-\varepsilon_{i} \cdot \cos \left(\beta_{\mathrm{i}}-\varphi_{\mathrm{i}}\right)$,

Equations of temperature distribution in lubricant gaps $(i=1,2)$ :

$$
\begin{aligned}
& {\left[\frac{\partial p_{i}^{*}}{\partial \varphi_{\mathrm{i}}}-6 \frac{\eta^{*}}{h_{i}^{*}} \frac{\omega_{i} \cdot R_{i}+\omega_{i} \cdot R_{i+1}}{\omega_{i} \cdot R_{i}}\right] \frac{\partial \mathrm{T}_{\mathrm{i}}^{*}}{\partial \varphi_{\mathrm{i}}}+\left(\frac{D_{i}}{B}\right)^{2} \frac{\partial p_{i}^{*}}{\partial \mathrm{z}^{*}} \frac{\partial T_{i}^{*}}{\partial z^{*}}+12} \\
& =\left(\frac{\partial p^{*}}{\partial \varphi_{\mathrm{i}}}\right)^{2}+\left(\frac{D_{i}}{B}\right)^{2}\left(\frac{\partial p^{*}}{\partial \mathrm{z}^{*}}\right)^{2}+12 \frac{\eta^{* 2}}{h_{i}^{* 4}} \frac{\left(\omega_{i} \cdot R_{i}-\omega_{i+1} \cdot R_{i+1}\right)^{2}}{\left(\omega_{i} \cdot R_{i}\right)^{2}}
\end{aligned}
$$

Vol. 3 No. 6 (June 2010)

ISSN: 0974- 6846
The condition of balance of frictional moments in a bearing can be written as:

$$
\alpha_{2} \int_{0}^{2 \pi}\left(\frac{1}{2} \cdot h_{2}^{*} \cdot \frac{\partial p_{2}^{*}}{\partial \varphi_{2}}+\frac{\eta^{*}}{h_{2}^{*}}\right) d \varphi_{2}=
$$

Equations of a lubricant factor condition:

$$
\eta_{\mathrm{i}}^{*}=\frac{\eta}{\eta_{0}}=\mathrm{e}^{a^{*} T_{i}^{*}+b^{*} \mathrm{~T}_{\mathrm{i}}^{* 2}}
$$

where: $a^{*}=a_{\eta} \cdot \frac{\eta_{0} \cdot \omega_{i}}{\rho \cdot c_{p} \cdot \psi_{i}^{2}}, b^{*}=b_{\eta} \cdot\left(\frac{\eta_{0} \cdot \omega_{i}}{\rho \cdot c_{p} \cdot \psi_{i}^{2}}\right)^{2}$

Having established boundary conditions for pressure and temperature areas the authors assumed that circumferential lubricant groove in the inner and outer bearings are completely filled up with oil.

\section{Equations of balance of powers and frictional moments:}

Boundary conditions of pressure area for these accepted assumptions are as follow:

- On the boundary separating a circumferential lubricant grooves and a bearing bush: $\mathrm{p}\left(\varphi_{\mathrm{i}},-\mathrm{B} / 2\right)=\mathrm{p}_{\mathrm{zi}}$,

- On the boundary separating a bearing bush and environment:

$p\left(\varphi_{i}, B / 2\right)=0$,

- On the boundary separating working and non-working

$$
\frac{\partial p_{i}}{\partial \varphi_{i}}=0
$$

- On the surface of both bearing bushes the following condition is fulfilled:

$$
\mathrm{p}_{\mathrm{i}}(<0.2 \pi>, \mathrm{z}) \geq 0,
$$

$F^{*} L 1 x=0, \quad F^{*} L 2 x=0, \quad F^{*} L 1 y=F_{1}^{*}, \quad F^{*} L 2 y=F_{2}^{*}$,

$M^{*}{ }_{2}\left(O_{J 2}\right)=M^{*}{ }_{3}\left(O_{J 2}\right)$,
To describe boundary conditions of temperature area authors have distinguished three zones:

- A zone containing a boundary that joins a bearing bush and a feed tubule, in which temperature has a constant value,
Research article

CIndian Society for Education and Environment (iSee)
"Floating ring bearing" http://www.indjst.org
A. Mazurkow Indian J.Sci.Technol. 
- A zone containing a boundary that joins a bearing bush and a circumferential lubricant grooves or a bearing bush and an environment, in which temperature has a variable value

- A zone that occurs on a bearing bush surface, in which pressure has a value equal to zero, it contains a boundary where oil is disappearing.

Essential conditions on boundaries of a bearing bush for solving equations of a temperature area are presented in Fig.3.

Where:

$$
\begin{array}{cc}
\beta_{x}=\frac{\eta\left(v_{x i}^{* *}+v_{z}^{* *}\right) \cdot v_{x i}^{*}}{\rho \cdot c_{p}\left(\left(v_{z}^{*}\right)^{2}+\left(v_{x i}^{*}\right)^{2}\right)}, & \beta_{z}=\frac{\eta\left(v_{x i}^{* *}+v_{z}^{* *}\right) \cdot v_{z}^{*}}{\rho \cdot c_{p}\left(\left(v_{z}^{*}\right)^{2}+\left(v_{x i}^{*}\right)^{2}\right)}, \\
v_{x i}^{*}=\int_{0}^{h} v_{x i} \cdot d y, & v_{z i}^{*}=\int_{0}^{h} v_{z i} \cdot d y, \\
v_{x i}^{* *}=\int_{0}^{h}\left(\frac{\partial v_{x i}}{\partial y_{i}}\right)^{2} \cdot d y, & v_{z i}^{* *}=\int_{0}^{h}\left(\frac{\partial v_{z i}}{\partial y_{i}}\right)^{2} \cdot d y
\end{array}
$$

Verification of a theoretical bearing model

Having examined the structure of oil supply system of a bearing in empirical studies it was assumed that it suited feeding method in a theoretical model. Network diagrams of parameters correlations:

- Input and resultant measurements

- Input values for calculations and examined resultant values are described in the Fig. 4

- The analysis of network diagrams suggests that for a verification of author's own model in numerical investigations as input values he should accept the following parameters from empirical studies:

- Pressure of oil feeder: $p_{z}$, feeding temperature: $T_{z}$,

- Oil thermophysical qualities: $\eta(T)$, $\rho(T), c_{p}(T), \lambda$,

- Geometry of a bearing $\mathrm{R}_{\mathrm{j}}, \mathrm{R}_{\mathrm{i}}, \mathrm{B}$,

- Angular velocity of a floating ring $\omega_{2}$.

Moreover, for calculations we should choose such a relative eccentricity value of the outer oil film $\varepsilon_{2}$ that a determined load capacity $F_{L}=F_{L 1 y}=F_{L 2 y}$ or an angular velocity of a bearing journal $\omega_{1}$ can be precisely consistent with measured values. The parameter value $\varepsilon_{2}$ can be found through an iterative method. The choice of one from above parameters depends on a gradient value of functions: http://www.indjst.org
Vol. 3 No. 6 (June 2010)

ISSN: 0974- 6846

$$
\frac{\partial F_{L}}{\partial \varepsilon_{2}}, \quad \frac{\partial n_{1}}{\partial \varepsilon_{2}} .
$$

The influence of a relative eccentricity of an outboard bearing on a relative growth of a journal angular velocity and a bearing load capacity is depicted in the Fig. 5 a.

The charts show (Fig. 5a) that the growth of a relative eccentricity of an outboard bearing causes the growth of a journal angular velocity and a bearing load capacity. When eccentricity range is $\varepsilon_{2}=0,2-0,9$, a relative increase of a journal angular velocity equals: $\Delta \omega_{1} / \omega_{1}=0,09$, whereas, a relative rise of a load capacity equals to: $\Delta F_{L} / F_{L}=27$. Therefore, for numerical calculations the author will take a journal angular velocity as an input value in comparative studies.

A qualification of compared parameters

Resultant values achieved in a numerical way and also treated as resultant measured parameters can be divided into three groups:

I group: $\mathrm{p}_{2}\left(\mathrm{x}_{2}, \mathrm{z}\right), \mathrm{T}_{2}\left(\mathrm{x}_{2}, \mathrm{z}\right), \varepsilon_{0}, \gamma_{0}$,

II group: $F_{L}=F_{L 2 y}$, or $\omega_{1}$,

III group: $M_{4}, Q_{m}$.

These three groups of resultant values will become the criteria for verifying a theoretical model of a bearing. The I and II groups include these parameters which fulfill basic criteria. Whereas, the III group includes these parameters whose values are calculated on the basis of well-known parameters from the I and II group. Parameters from the III group will be treated as additional criteria.

Fig. 1. Sliding bearing with a floating ring: 1- fixed bearing bush, 2- floating ring, 3holes trough which oil is supplied to bearing, 4- circumferential lubricant grooves, 5- the directions of oil flow

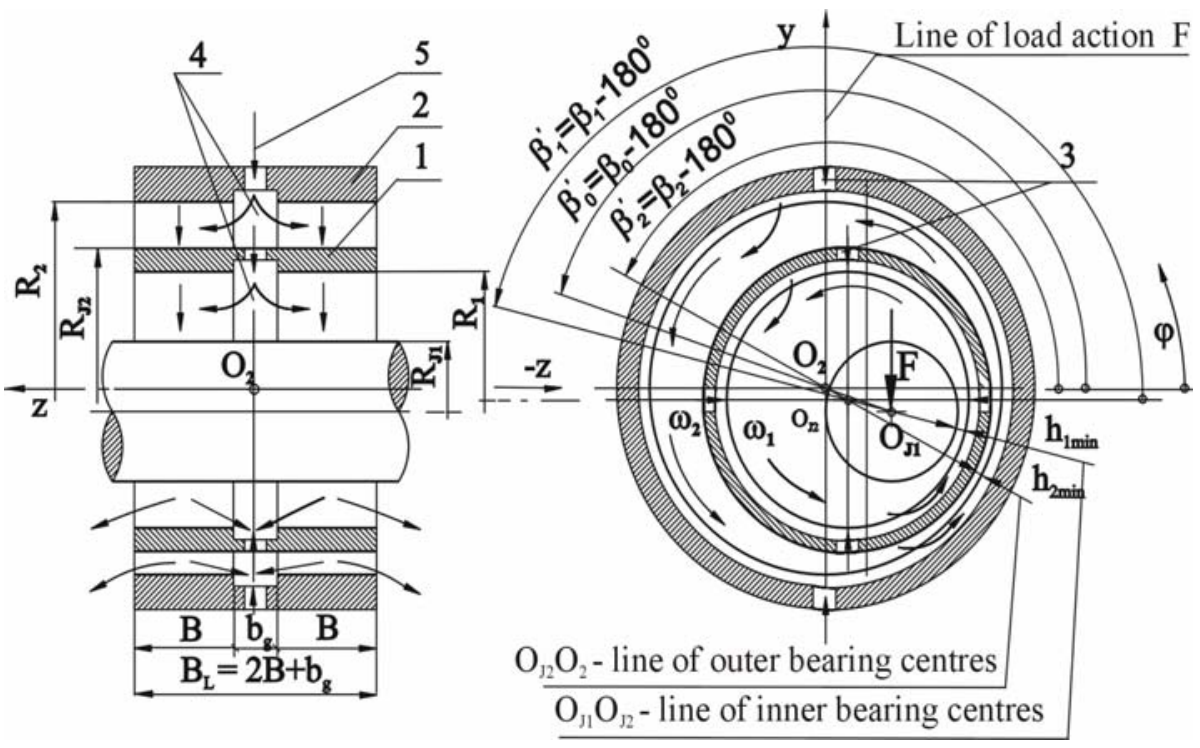

"Floating ring bearing"
A. Mazurkow Indian J.Sci.Technol. 
Indian Journal of Science and Technology

Fig. 2. System of forces and moments in a bearing

Vol. 3 No. 6 (June 2010)

ISSN: 0974- 6846
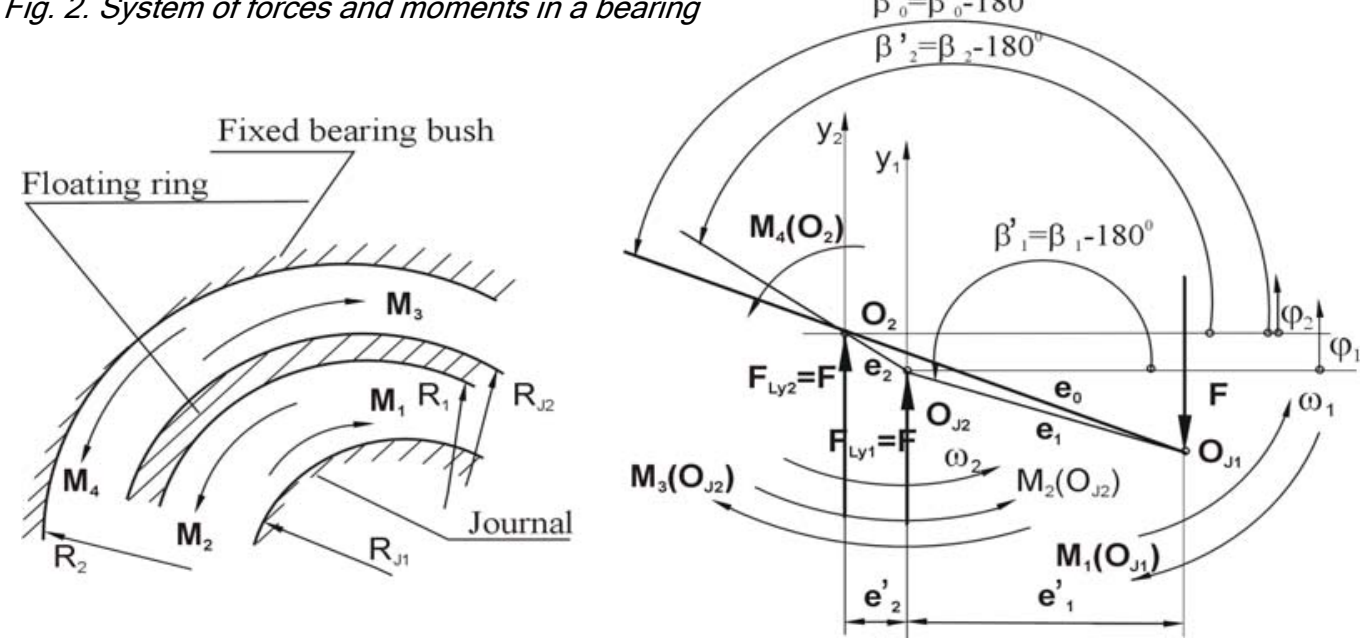

Fig. 3. Boundary conditions of temperature area

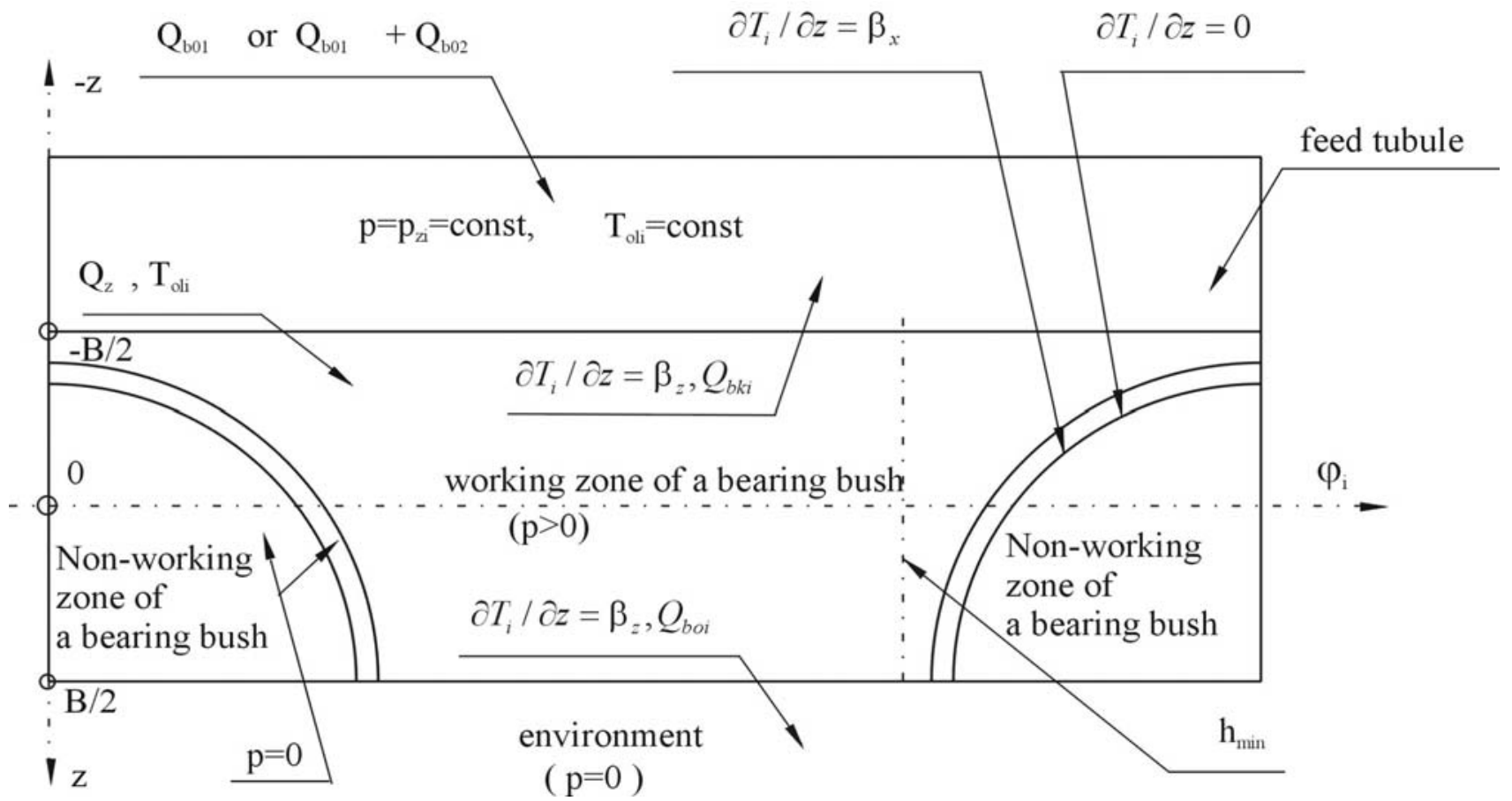

Fig. 4. The network diagram of parameters correlations:

a) input and resultant measurements

b) input values for calculations and also calculated resultant values.

Research article

CIndian Society for Education and Environment (iSee)
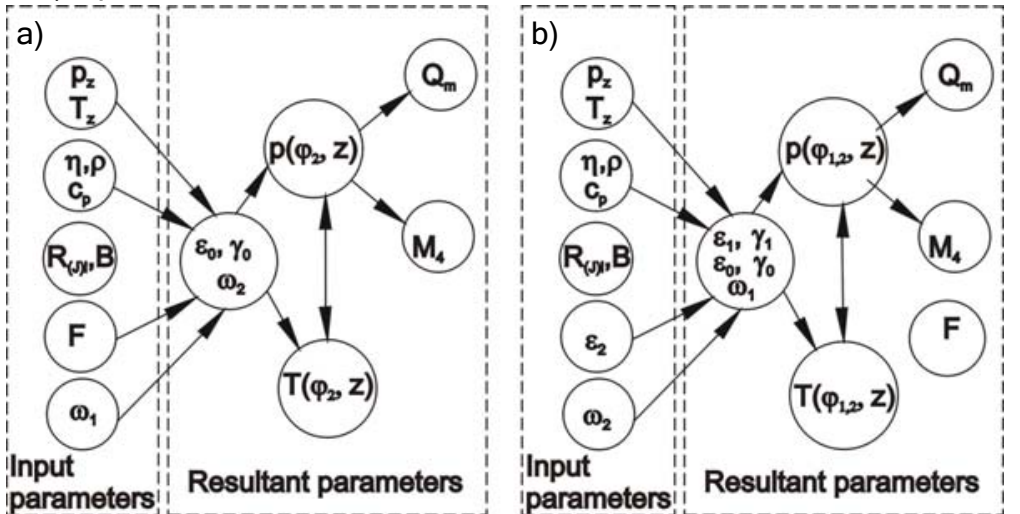

"Floating ring bearing"

http://www.indjst.org
A. Mazurkow Indian J.Sci.Technol. 
Indian Journal of Science and Technology

Fig. 5 a). The influence of a relative eccentricity of an outer bearing on the relative growth of a journal angular velocity and a bearing load capacity

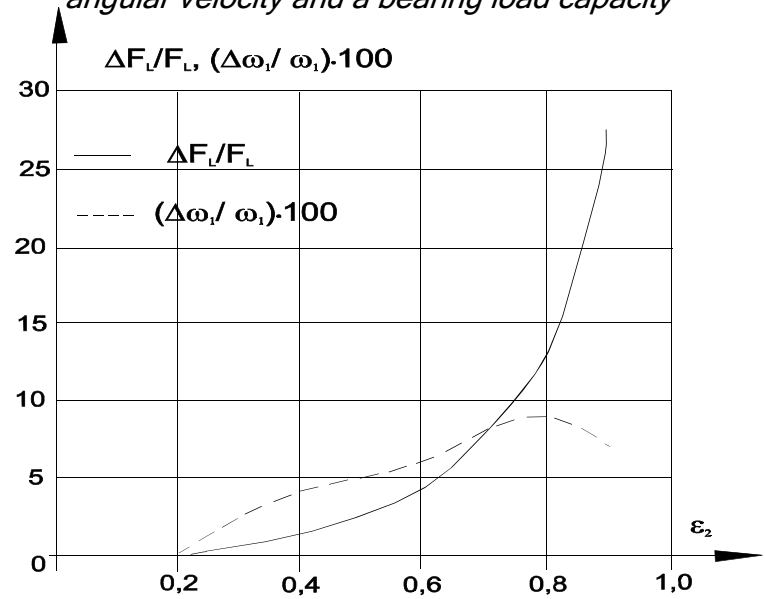

Vol. 3 No. 6 (June 2010)

ISSN: 0974- 6846

Fig.5b). The comparison of frictional moments on the surface of a fixed bearing bush in the function of a bearing journal angular velocity

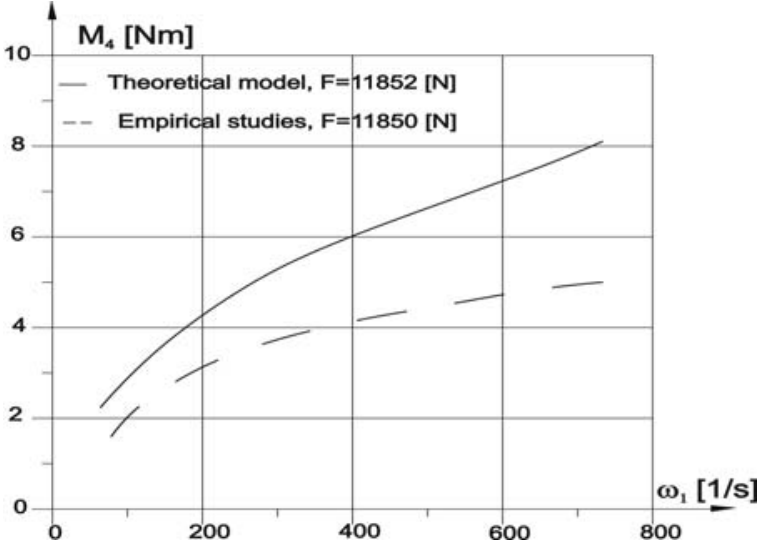

Fig. 6. a) The comparison of pressure distributions in an outer lubricant gap for $z=0$, in the section consistent with a circumferential coordinate direction, b) The comparison of temperature distributions in an outer lubricant gap for $z=B / 6$ in the section consistent with a circumferential coordinate direction, $c$, d) The comparison of temperature distributions in an outer lubricant gap for $\varphi_{2}=0^{\circ}, 180^{\circ}$ and $135^{\circ}, 315^{\circ}$, in sections consistent with an axial coordinate direction
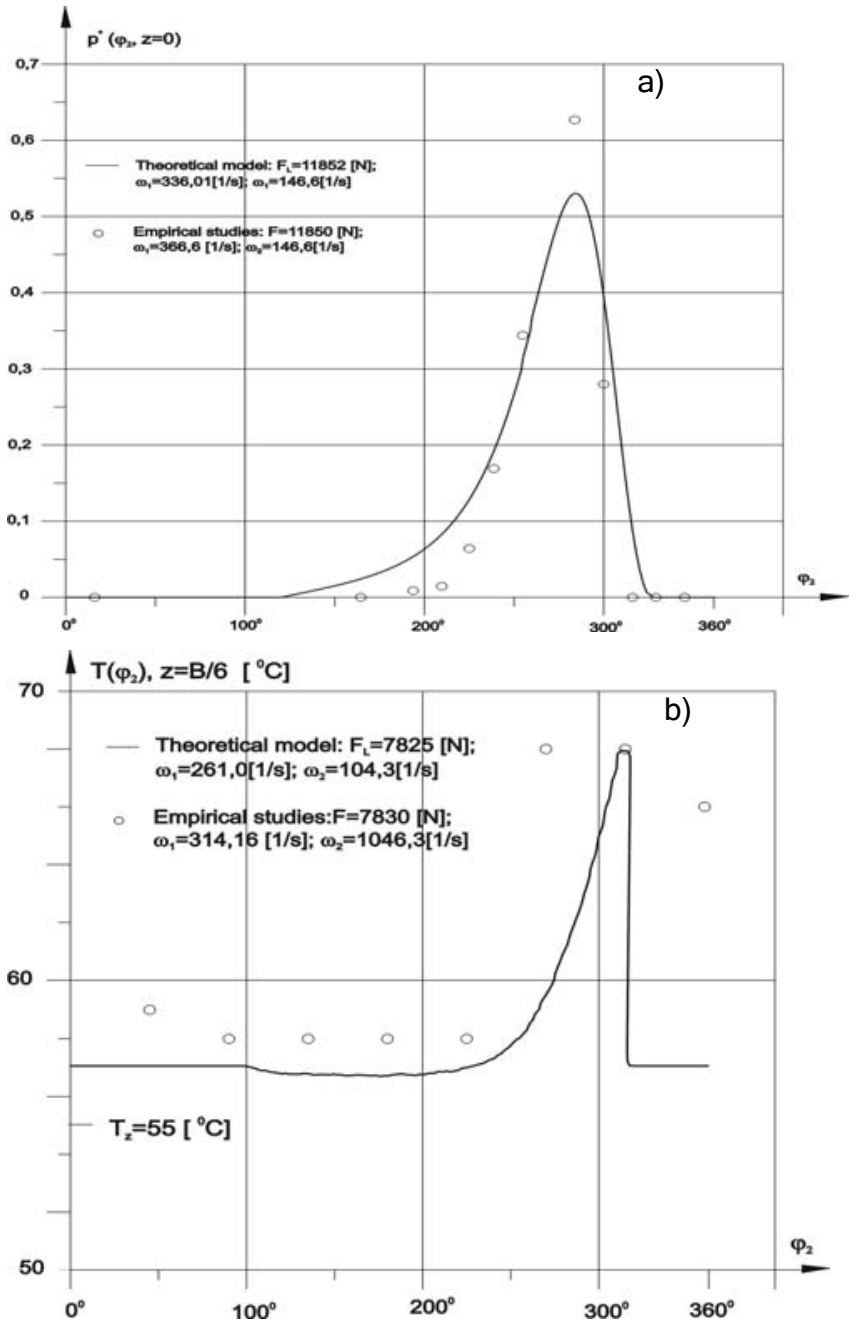

"Floating ring bearing"

Research article CIndian Society for Education and Environment (iSee)

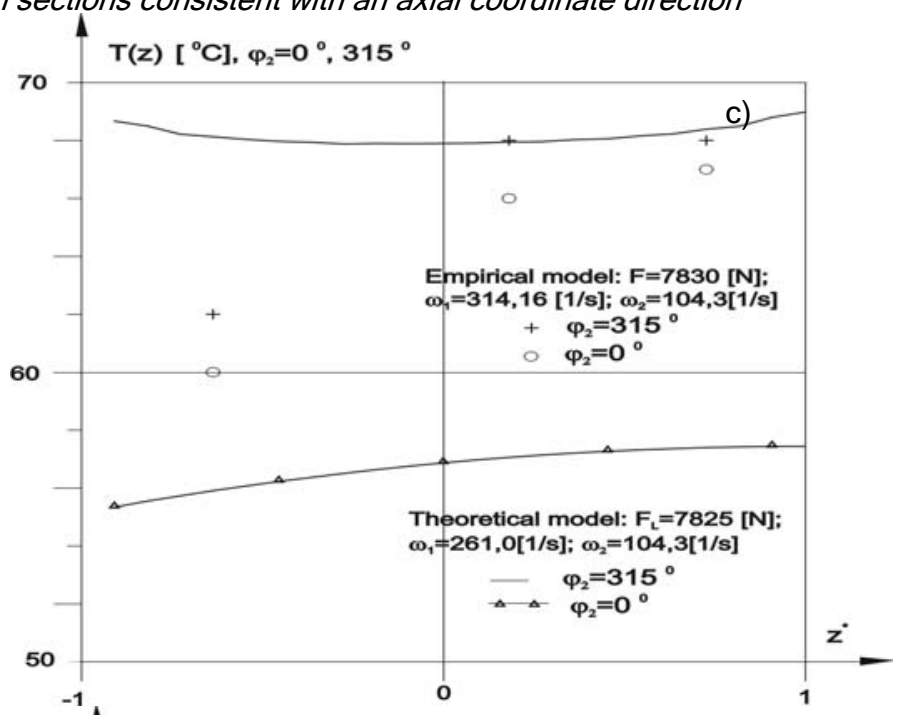

$T(z)\left[{ }^{\circ} \mathrm{C}\right], \varphi_{2}=135^{\circ}, 180^{\circ}$

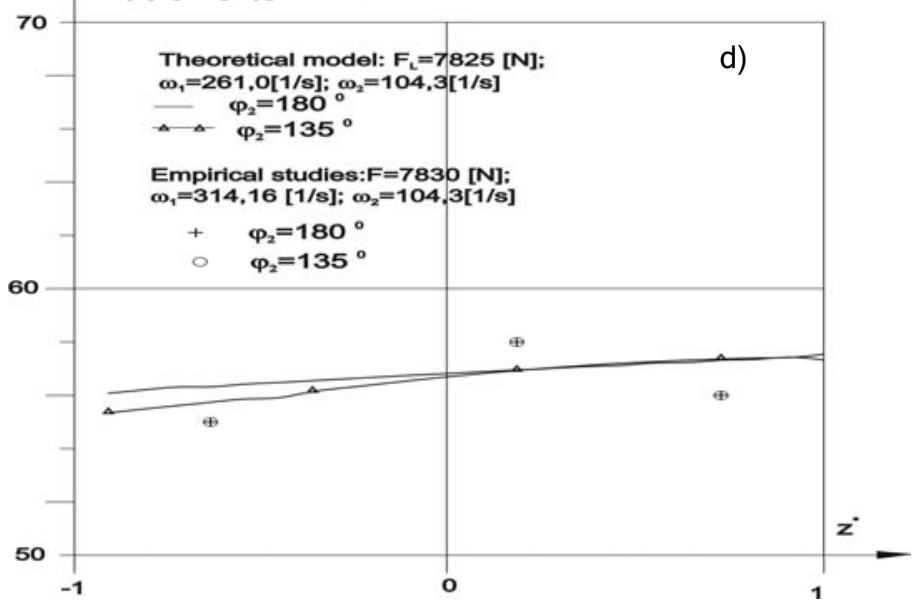

A. Mazurkow Indian J.Sci.Technol. 
Comparative studies of pressure distribution, temperature, position of a journal centre towards a fixed bearing bush

For numerical counts we accepted input values from our experiments which are presented in the Table 1.

$\eta(T)=\eta_{o} \cdot e^{a_{\eta} \cdot\left(T-T_{0}\right)+b_{\eta} \cdot\left(T-T_{0}\right)^{2}}$,

$\rho(T)=a_{\rho}+b_{\rho} \cdot T+d_{\rho} \cdot T^{2}$,

$c_{p}(T)=a_{c}+b_{c} \cdot T+d_{c} \cdot T^{2}, \lambda=0,145$, where:

$\eta_{\mathrm{o}}=0,1084, \mathrm{a}_{\eta}=-0,55291 \cdot 10^{-1}, \mathrm{~b}_{\eta}=-0,239 \cdot 10^{-3}, \mathrm{a}_{\mathrm{\rho}}=896,25$, . $b_{p}=-1,437, d_{p}=0,625 \cdot 10^{-2}, a_{c}=1802,1, b_{c}=2,878, d_{c}=0,87 \cdot 10^{-2}$.

As a result of numerical counts we received pressure and temperature distributions in the outer lubricant gap. Distributions in sections consistent with a circumferential coordinate and equivalent to their measured points are

Table1. The comparison of operation parameters in a theoretical model with empirical studies results

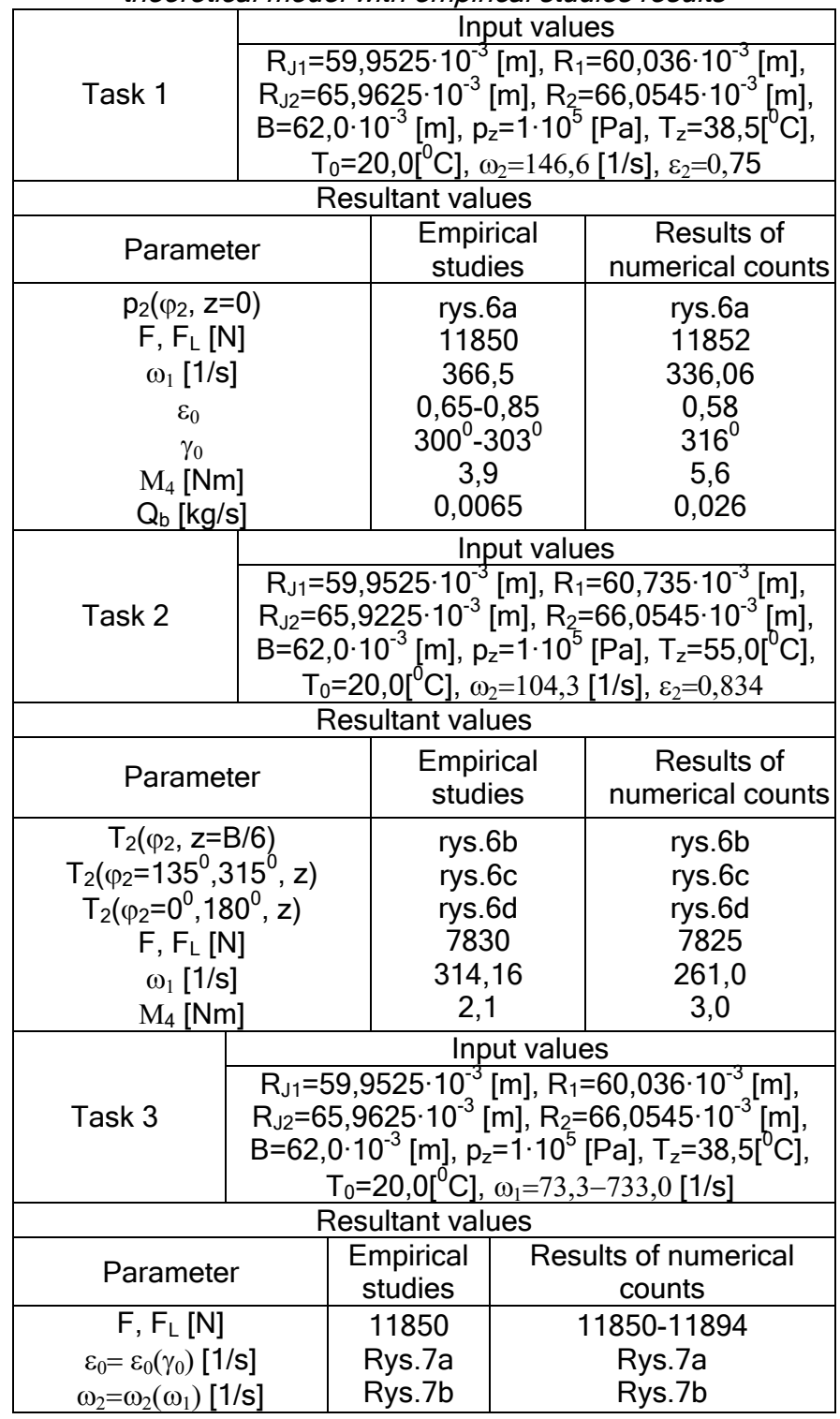

Research article

CIndian Society for Education and Environment (iSee)

"Floating ring bearing" http://www.indjst.org
Vol. 3 No. 6 (June 2010)

ISSN: 0974- 6846

Fig. 7. a) The comparison of journal centre positions established towards a fixed bearing bush

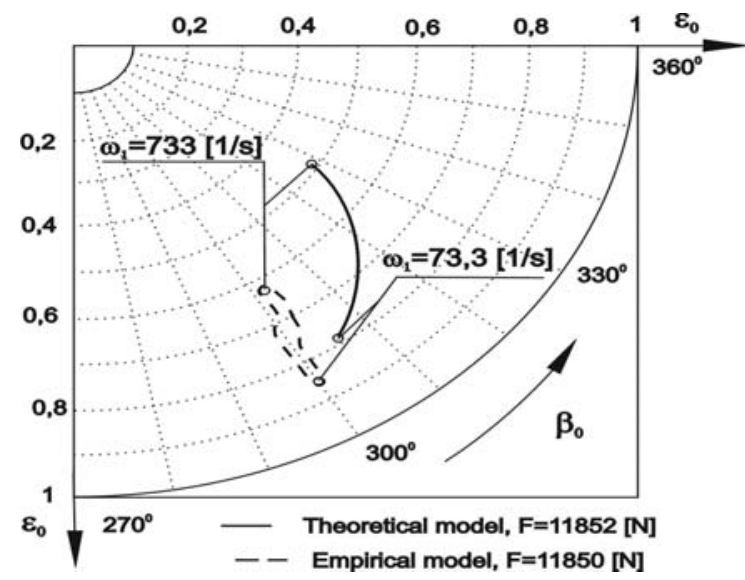

7b) The comparison between a floating ring bearing angular speed and a bearing journal angular speed

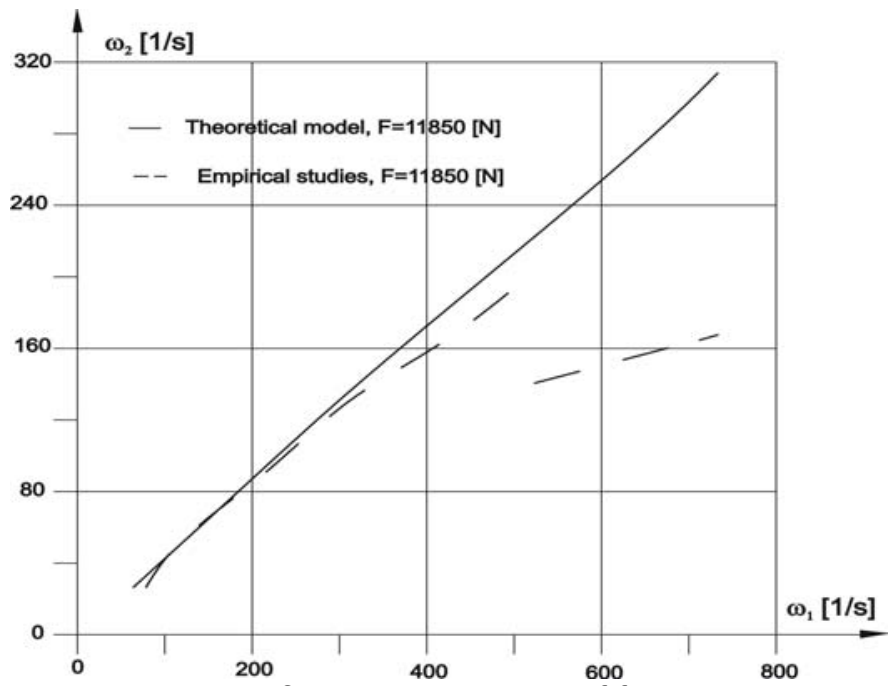

shown in the Fig.6. The comparison of frictional moments on the surface of a fixed bush is described in Fig.5b. The comparison of a journal positions in relation to a fixed bush is presented in Fig.7a. The comparison of an angular velocity of a floating ring bearing in the function of a bearing journal angular velocity is described in Fig. 7b. The comparison of other parameters is given in Table 1.

\section{Conclusion}

On the basis of a developed method the author carried out the verification of a theoretical model of a slide bearing with a floating ring bearing. The evaluation criteria of a theoretical model were presented in regard to results from empirical studies. These criteria were divided into three groups. As the basic criteria the author accepted the position of a bearing journal centre towards a fixed bearing bush, also for these positions he chose pressure and temperature distributions in the outer oil film. These studies constitute the part of a verification method of theoretical models of sliding bearings developed by the author.

These investigations lead to the following conclusions:

a) Comparison tests of pressure distributions (Fig. 6a): 
- Character of a pressure function course for a section compatible with a circumferential direction in the coordinate system, the function obtained through theoretical calculations comes to a big compatibility with pressure distribution calculated in an empirical way.

- Value of a maximum pressure obtained during measurements is smaller than a value obtained in author's own experiments and differs about a relative error equals $\delta p_{\max }=0,1$.

- In comparison to experimental researches, in the author's own examinations in circumferential coordinate direction, boundaries position established for a constant oil film lengthens a zone in which pressure is higher than zero.

Operation parameters of a bearing calculated in these studies in comparison with measured values show differences which described by a relative error are equal to: $\delta F_{L}=17 \cdot 10^{-5}, \delta \omega_{1}=9 \cdot 10^{-2}, \delta M_{4}=3 \cdot 10^{-1}, \delta Q_{b}=75 \cdot 10^{-2}$

b) Comparison tests of temperature distribution

(Fig. 6b, c, d):

- Character of a temperature distribution course in circumferential coordinate direction received through measurement reaches compatibility with a pressure function course calculated in a numerical way.

- There is a divergence concerning temperature courses determined in sections which are led towards an axial coordinate direction. In the author's own examinations a temperature distribution in the area where $p=0$ has a character of a linear function with increasing values in an oil flow direction from a bearing bush. Whereas, measured temperature values reveal the character of a parabolic curve with the maximum which appears near a bearing bush axis. On the one hand, in the area where $p>0$ measured temperature distributions show the character of parabolic curves, the maximum value of temperature appears in the zone where oil flows away from a bush. On the other hand, a distribution numerically calculated behaves like a curve whose maximum occurs in the oil outflow zone in a bearing bush. The boundary

- that joins a circumferential lubricant groove and a bush in the area where oil flows away from a circumferential lubricant groove towards a bush, an oil temperature is equal to $\mathrm{T}_{\mathrm{ol} 2}=55\left[{ }^{0} \mathrm{C}\right]$. The temperature in a circumferential lubricant groove characterizes itself with its fall near the groove.

c) Comparison tests of frictional moments on the surface of a fixed bearing bush (Fig. 5b), the position of a journal centre in relation to a fixed bearing bush (Fig.7a), angular velocities of a floating ring bearing in relation to a bearing journal (Fig. 7b):

- Frictional moments on the surface of a fixed bearing bush in the whole analyzed process of journal angular velocities in comparison to measurements take higher values, divergences increase together with the growth of a bearing journal angular velocity.

- For accepted load $\mathrm{F}=11850[\mathrm{~N}]$, in speed range studies $\omega_{1}=73,3-733[1 / \mathrm{s}]$ values calculated from the theoretical model and concerning the position of a bearing journal centre relative to a fixed bearing bush $\left(\varepsilon_{0}\right)$ are smaller than measured values. Whereas, calculated angle values $\left(\beta_{0}\right)$ corresponding with relative eccentricities $\left(\varepsilon_{0}\right)$ are bigger than measured values.

- Character of a function course $\omega_{2}=\omega_{2}\left(\omega_{1}\right)$ received by measuring is consistent with a function course achieved during numerical calculations. We can see divergences in higher angular velocities of a bearing journal. When speed equals $\omega_{1} \approx 500$ [1/s] a bearing journal behaves unsteadily. In numerical calculations there aren't any instabilities in a journal operation, a function course is continuous. The reasons of the instability in operations of slide bearings with a floating ring are described in the following research works (Buluschek, 1980; Mazurkow, 1993; Kicinski, 2005; Mazurkow, 2009).

d) Causes of differences between measured or calculated values

The reasons of above mentioned differences should be , looked for either in a developed theoretical model of a bearing or in errors of a measuring method, i.e:

- Defects in a theoretical model which describes the position of constant oil film boundaries result from the assumption of endlessly big lubricant strength on stretching.

- In an accepted thermal model which describes a heat flow in a bearing we do not take into account a heat transfer through bushes and journal surfaces.

- Measurements reveal that the position of a journal axis, a fixed bush or a floating ring bearing is not parallel- where a theoretical model of a bearing was designed for a parallel position of above axis's (Buluschek, 1980).

-Analysis of temperature distributions achieved in experiments let that misalignment of both a shaft axis and bearing bushes on operation parameters of a bearing is big (Kameron, 1962; Kotynia, 1982). Now, the author is working on the structure of the theoretical model of a slide bearing with a floating ring bearing to deal with the effect of the misalignment of a shaft axis and a floating ring bearing.

\section{References}

1. Buluschek B (1980) Das Schwimmbüchsenlager bei stationärem Betrieb. Diss. ETH, 1-87.

2. Kameron A (1962) Teoria smazki w inzynierskom diele. G. N. I. M. L, Moskwa, 26-41.

3. Kaniewski W (1977) Warunki brzegowe diatermicznego filmu smarnego.. Zeszyty naukowe Politechniki Łódzkiej. Zeszyt specjalny, z.14, 1-10.

4. Kiciński J (2005).: Dynamika wirników i łożysk ślizgowych. Instytut Maszyn Przepływowych im. R. Szewalskiego PAN, tom 28. Gdańsk, 321-333.

5. Kotynia W (1982) Termohydro-dynamiczne charakterystyki hiperboidalnych łożsk ślizgowych. Praca doktorska. Łódż, 166.

6. Mazurkow A (1993) Termodyn-amiczna teoria smarowania i statyczne charakterystyki ślizgowego łożyska poprzecznego z panewką pływającą. Praca doktorska, Politechnika Rzeszowska, 1-77.

7. Mazurkow A (2009) Właściwości statyczne i dynamiczne, metoda projektowania łożysk ślizgowych $\mathrm{z}$ panewką pływającą. Oficyna wydawnicza Politechniki Rzesz -owskiej. Rzeszów, 116-125.

8. Mazurkow A (2009) Niepublikowane materiały Katedry Konstrukcji Maszyn. Politechnika Rzeszowska, Rzeszów.127.
Research article

CIndian Society for Education and Environment (iSee)
"Floating ring bearing"

http://www.indjst.org
A. Mazurkow Indian J.Sci.Technol. 